MENTAL

HEALTHLAW

PROFILE

\title{
Mental health law in Serbia - an important step towards destigmatisation
}

\author{
Dusica Lecic Tosevski, ${ }^{1}$ Saveta Draganic Gajic, ${ }^{2}$ Milica Pejovic Milovancevic ${ }^{2}$ \\ and Slavica Djukic Dejanovic ${ }^{3}$
}

1 Professor, Belgrade University School of Medicine; Director, Institute of Mental Health, WHO Collaborating Centre Belgrade, Serbia, email dusica. lecictosevski@eunet.rs

${ }^{2}$ Medical Faculty, University of Belgrade; Institute of Mental Health, Belgrade, Serbia

${ }^{3}$ Medical Faculty, University of Kragujevac; Psychiatric Clinic, Kragujevac; Psychiatric Clinic,
Clinical Centre Kragujevac, Serbia
Serbia has, along with other countries in the region, begun reform of its mental healthcare services. The delivery of mental healthcare was hitherto only partially regulated by law. Hence the National Committee for Mental Healthcare in Serbia has prepared a draft Mental Health Law within the context of a multicentre project entitled 'Enhancing social cohesion through strengthening community care' as part of the Stability Pact for South Eastern Europe. It is expected that new mental health legislation will soon be approved by Parliament and lead to the implementation of changes concerning mental healthcare. It should contribute to the destigmatisation of patients, mental health professionals and psychiatry as a discipline.

\section{Stigma and social exclusion}

Mental disorders constitute a large group of heterogeneous disorders affecting over $25 \%$ of the population at different stages of their lives, regardless of their gender, age, educational or social status and background (World Health Organization, 2003a). According to estimates, mental disorders are the cause of $12.3 \%$ of years lost due to diseases and injuries, and $30.8 \%$ of years lived with disability, and represent 3 of the 20 leading causes of death throughout the world (World Health Organization, 2003b). The prevalence of mental disorders in Serbia increased by $13.5 \%$ between 1999 and 2001, to become the second largest public health problem in the country (Lecic Tosevski et al, 2010).

Patients with mental health problems are stigmatised by lay persons, the media - which are prone to reporting sensationalist news - and even medical professionals. Along with their patients, psychiatrists, mental health workers and the specialty of psychiatry itself are also stigmatised.

Individuals suffering from mental health problems are subject to breaches of their human rights, especially those in the large psychiatric hospitals, where patients sometimes remain for many years, often due to the lack of social support systems. Involuntary treatments have often included physical restraint without adequate supervision or control. More generally, patients are excluded from any decision-making in their own treatment process. These practices have taken place in the context of discrimination and the isolation of the patient from the work setting, from the family and from the community, which fosters the general image of psychiatric patients as being out of control and dangerous to society.

\section{Regional cooperation}

In Serbia, mental health practice is currently only partially regulated by law and the rights of persons with a mental illness are only partially protected. The legislation does not address issues such as informed consent and involuntary treatment - matters elsewhere regulated by international declarations and conventions on human rights. Serbia started the reform of mental healthcare in 2002 by joining the project 'Enhancing social cohesion through strengthening community care' as part of the Stability Pact for South Eastern Europe. Nine countries were involved in the project: Albania, Bosnia and Herzegovina, Bulgaria, Croatia, Former Yugoslav Republic of Macedonia, Moldova, Montenegro, Romania and Serbia. The project had three basic goals (Lecic Tosevski et al, 2007, 2008):

- the harmonisation of mental healthcare in the region

- the preparation of mental health laws

- the development of community mental healthcare.

It led to the National Strategy for Development of Mental Healthcare, a document prepared by the National Committee for Mental Healthcare of the Republic of Serbia, which was approved by the government in January 2007 (Ministry of Health, 2007). One of the goals of that strategy was the improvement of legislation related to the rights of persons with a mental illness.

\section{Mental health law - a long way from draft to expected approval}

The first draft of the mental health law was prepared by the National Committee for Mental Healthcare in October 2003. It was presented at many meetings of mental health experts, representatives of social institutions and local authorities in different towns in Serbia. Professional associations as well as non-governmental organisations were consulted on the draft legislation and made a number of constructive suggestions. The draft law was reviewed by: Julio Arboleda-Florez, Professor of Forensic Psychiatry, Queen's University, Canada; Svetlana Poluminskaya, Institute of 
Law, Russian Academy of Sciences, Moscow; Paolo Serra, Caritas, Italy; Robert van Voren, Geneva Initiative on Psychiatry, the Netherlands; and Richard J. Bonnie, attorney at the Geneva Initiative on Psychiatry, and Professor of Law, University of Virginia, USA.

Close cooperation was established with regional experts, through continuous discussions and consultations at official technical seminars of the 'Enhancing social cohesion' project, or at other international meetings. Of invaluable help was the material within the "Mental Health Policy and Service Guidance Package', prepared by a group of experts from the World Health Organization, and particularly the Manual on Legislation and Human Rights (World Health Organization, 2003c). In the course of drafting the law, a long list of international charters, regulations and standards was referred to. They are listed in the Appendix of the draft document.

The draft law was submitted to the Ministry of Health in December 2004. The long process that followed resulted in the Mental Health Law being provisionally approved in 2005 , with three other versions reaching the next stages of approval in 2009, 2010 and 2011. The need to harmonise a number of other laws with European legislation was a priority for the Serbian Parliament and resulted in the postponement of the final approval of mental health legislation. It is quite possible that the marginalisation of mental illness was an additional reason for the delay.

The proposed Mental Health Law deals with the basic principles, organisation and implementation of mental healthcare, as well as matters directly related to patients' experiences. It addresses the full affirmation of the rights of persons with mental disorders, including prevention, mental health promotion, treatment and psychosocial rehabilitation in the community, as well as the recovery of persons with mental disorder and their integration in family, professional and social settings. Research should require the informed consent of participants or proxy consent. Associations of persons with mental disorders should be established, to help patients exercise their rights, to provide help and to promote self-help, and to have an influence on health policy planning and implementation, partially through the involvement of family members, legal representatives, other interested parties and the community in general. These objectives as well as the control and supervision of the work of institutions and professionals treating persons with mental disorders represent some of the main principles underlying the legislation, along with non-discrimination, protection of dignity, non-abuse and protection of specific groups (minors, women and minorities).

The Mental Health Law also regulates treatment, ensuring that care is individualised and person-centred (Lecic Tosevski, 2009). Principles underlying involuntary admission and in-patient treatment are adumbrated by reference to published research (Jovanovic et al, 2009). The law covers the rights and obligations of persons with mental disorders and addresses issues of confidentiality. Procedures such as discharge from a psychiatric institution, the proper application of physical restraint and seclusion, and special treatments (electroconvulsive therapy, biomedical research) are also covered.

\section{Current and future developments}

The Ministry of Health established a working group in 2010 with the aim of revising the most recent draft of these provisions and aligning mental health legislation to already existing and approved legislation from related areas. Consultations were held at several conferences in the drafting of the Mental Health Law, and suggestions and comments were incorporated. The Ministries of Justice and of Social Welfare were also included in the process. The final draft has been forwarded to the government for approval.

We hope that the implementation of the Mental Health Law in Serbia will lead to the integration of several important areas of activity concerning mental healthcare, including deinstitutionalisation (without trans-institutionalisation); the social inclusion of persons with a mental illness; personcentred treatment; and the humanisation of the doctor-patient relationship. The implementation of this new legislation will represent a historic moment for both the country and the profession, and should contribute to the destigmatisation of both patients and mental healthcare.

\section{References}

Jovanović, A., Jašović Gašić M. \& Lečić Toševski, D. (2009) Medikolegalni aspekti bolničkog zbrinjavanja osoba sa duševnim poremećajem koje ispoljavaju nasilno ponašanje [Medico-legal aspects of the hospital care of persons with mental disorders]. Srpski arhiv za celokupno lekarstvo, 137, 292-297.

Lecic Tosevski, D. (2009) Psychiatry for the person and social transition. European Psychiatric Review, 1(2), 37

Lecic Tosevski, D., Pejovic Milovancevic, M. \& Popovic Deusic, S. (2007) Reform of mental health care in Serbia: ten steps plus one. World Psychiatry, 6, 51-55.

Lecic Tosevski, D., Christodoulou, G. N., Kontaxakis, V., et al (2008) Provision of psychiatric services and mental health care reform in Eastern Europe and the Balkans. European Psychiatric Review, 1(1), 9-11.

Lecic Tosevski, D., Draganic Gajic, S. \& Pejovic Milovancevic, M. (2010) Mental healthcare in Serbia. International Psychiatry, 7. $13-15$

Ministry of Health, Republic of Serbia (2007) National Strategy for Development of Mental Healthcare. Ministry of Health.

World Health Organization (2003a) The Mental Health Context (Mental Health Policy and Service Guidance Package). WHO.

World Health Organization (2003b) World Health Report 2001 Mental Health: New Understanding, New Hope. WHO.

World Health Organization (2003c) Manual on Legislation and Human Rights (Mental Health Policy and Service Guidance Package). WHO.

\section{Note added in proof}

The Mental Health Law was approved by Parliament in May 2013, after this paper was submitted. 